\title{
FREQUENCY OF ANTIBODIES TO Babesia bigemina, B. bovis, Anaplasma marginale, Trypanosoma vivax AND Borrelia burdgorferi IN CATTLE FROM THE NORTHEASTERN REGION OF THE STATE OF PARÁ, BRAZIL
}

\author{
DANIEL S. GUEDES JUNIOR ${ }^{1}$; FLÁBIO R. ARAÚJO ${ }^{2}$; FÁBIO J.M. SILVA ${ }^{1}$; CHARLES P. RANGEL ${ }^{1}$; \\ JOSÉ D. BARBOSA NETO ${ }^{3}$; ADIVALDO H. FONSECA ${ }^{4}$
}

\begin{abstract}
GUEDES JUNIOR, D.S.; ARAÚJO, F.R.; SILVA, F.J.M.; RANGEL, C.P.; BARBOSA NETO, J.D.; FONSECA, A.H. Frequency of antibodies to Babesia bigemina, B. bovis, Anaplasma marginale, Trypanosoma vivax and Borrelia burgdorferi in cattle from the Northeastern region of the State of Pará, Brazil. [Freqüência de anticorpos para Babesia bigemina, B. bovis, Anaplasma marginale, Trypanosoma vivax e Borrelia burgdorferi em bovinos do nordeste do Estado do Pará, Brasil]. Revista Brasileira de Parasitologia Veterinária v. 17, n. 2, p. 105109, 2008. Departamento de Epidemiologia e Saúde Pública, Instituto de Veterinária, Universidade Federal Rural do Rio de Janeiro, BR 456, Km7, Seropédica, RJ 23890-000. E-mail: adivaldo@ufrrj.br

Babesiosis, anaplasmosis, and trypanosomosis are relevant diseases, potentially causing morbidity in cattle, leading to economic losses. Borreliosis is import as a potential zoonosis. The objective of this study was to determine, by indirect enzyme-linked immunosorbent assay (ELISA), the frequency of seropositive cattle to Babesia bigemina, B. bovis, Anaplasma marginale, Trypanosoma vivax and Borrelia burgdorferi in cattle from the Northeastern region of Pará, Brazil. Sera samples from 246 female adult cattle from municipalities of Castanhal and São Miguel do Guamá were used. Crude antigens ELISAs were used to detect antibodies to all agents, except to A. marginale, to which an indirect ELISA with recombinant major surface 1a protein (MSP1a) antigen was used. Overall frequencies of seropositive animals were: B. bigemina - 99.2\%; B. bovis - 98.8\%; A. marginale - 68.3\%; T. vivax $-93.1 \%$ and $B$. burgdorferi $-54.9 \%$. The frequencies of seropositive cattle to $B$. bovis and $B$. bigemina suggest a high rate of transmission of these organisms by tick in the studied region, which can be classified as enzootically stable to these hemoprotozoans. The low frequency of seropositive cattle to A. marginale may be attributed to a lower sensitivity of the recombinant antigen ELISA utilized or a distinct rate of inoculation of this rickettsia by ticks, as compared with Babesia sp. transmission. The high frequency of seropositive cattle to $T$. vivax indicates that this hemoprotozoan is prevalent in herds from the Northeastern region of Pará. The rate of animal that showed homologues antibodies to $B$. burgdorferi indicates the presence of the tickborne spirochaetal agent in the cattle population in the studied region.
\end{abstract}

KEYWORDS: Babesia sp., Trypanosoma vivax, Anaplasma marginale, Borrelia sp., antibodies.

\footnotetext{
${ }^{1}$ Curso de Pós-Graduação em Ciências Veterinárias, Universidade Federal Rural do Rio de Janeiro, Rodovia BR465, km7, Seropédica, RJ 23890000. E-mail: guedesjr@ufrrj.br

${ }^{2}$ Embrapa Gado de Corte, Rodovia BR262, km 4, Campo Grande, MS 79002-970. E-mail: flabio@cnpgc.embrapa.br

${ }^{3}$ Universidade Federal do Pará, Centro Agropecuário, Departamento de Ciência Animal. Rua Maximino Porpino da Silva, 1000, Centro Castanhal, PA 68748-080. E-mail: Diomedes@ufpa br

${ }^{4}$ Departamento de Epidemiologia e Saúde Pública, Instituto de Veterinária, Universidade Federal Rural do Rio de Janeiro, BR 456, Km7, Seropédica, RJ 23890-000. E-mail: adivaldo@ufrrj.br
}

\section{RESUMO}

A babesiose, a anaplasmose e a tripanossomose são enfermidades relevantes, potencialmente causadoras de morbidade em bovinos, levando a perdas econômicas. A borreliose assume importância como zoonose potencial. O objetivo desse estudo foi determinar, por meio do ensaio de imunoadsorção enzimática (ELISA), a freqüência de anticorpos para Babesia bigemina, B. bovis, Anaplasma marginale, Trypanosoma vivax e Borrelia burgdorferi em bovinos da região nordeste do Es- 
tado do Pará, Brasil. Amostras de soro de 246 vacas dos municípios de Castanhal e São Miguel do Guamá foram usadas. ELISAs com antígeno bruto foram utilizados para detector anticorpos contra todos os agentes, exceto para A. marginale, para o qual um ELISA indireto com proteína principal de superfície 1a (MSP1a) foi usado. As freqüências de bovinos soropositivos foram: B. bigemina - 99,2\%; B. bovis - 98,8\%; A. marginale $-68,3 \%$; T. vivax $-93,1 \%$ and $B$. burgdorferi$54,9 \%$ As freqüências de bovinos soropositivos para $B$. bovis e $B$. bigemina sugerem uma alta taxa de transmissão desses organismos por carrapatos, na região estudada, a qual pode ser classificada com sendo de estabilidade enzoótica para os hemoparasitos. A baixa freqüência de bovinos soropositivos para A. marginale pode ser atribuída a uma menor sensibilidade do ELISA com antígeno recombinante, ou uma menor taxa de inoculação da riquétsia pelos carrapatos, quando comparada àquelas observadas para Babesia sp. A alta freqüência de bovinos soropositivos para T. vivax indica que esse hemoprotozoário é prevalente em rebanhos do nordeste do Estado do Pará. O percentual de animais com anticorpos homólogos para $B$. burgdorferi indica a presenças deste espiroquetídeo transmitido por carrapatos na população de bovinos da região estudada.

PALAVRAS-CHAVE: Babesia sp., Trypanosoma vivax, Anaplasma marginale, Borrelia sp., anticorpos.

\section{INTRODUCTION}

Bovine hemoparasitic diseases cause important economic loss in tropical, subtropical, and humid equatorial areas, mainly due to the high morbidity and mortality in susceptible cattle herds. However, the most important economic constraint of hemoparasitic diseases to cattle production is on programs for genetic improvement of cattle, as imported Bos taurus cattle brought from temperate nations for breed improvement are highly susceptible to tick-borne diseases and often do not survive to become part of planned reproduction programs (MELENDEZ, 2000; KOCAN et al., 2003).

In Brazil, bovine babesiosis and anaplasmosis are caused by protozoans Babesia bigemina and B. bovis and by rickettsia Anaplasma marginale, respectively. During the acute infection, these pathogens cause anemia, low weight gain, reduction in milk production, and even mortality of susceptible animals (KOCAN et al., 2003; BOCK et al., 2004).

The distribution of B. bigemina, B. bovis, and A. marginale follows the dissemination of their vectors. In Brazil, the former agents are transmitted by Rhipicephalus (Boophilus) microplus, while the latter one, besides biological transmission by tick, can also be mechanically transmitted by hematophagous diptera (GUGLIELMONE, 1995). Epidemiological studies showed that, in Brazil, B. bovis, $B$. bigemina and A. marginale are endemic in several areas (ARAÚJO et al., 1998; SMITH et al., 2000; SOARES et al., 2000; SOUZA et al., 2000; MELO et al., 2001; ARAÚJO et al., 2005; BARROS et al., 2005, D’ANDREA et al., 2006). Other factor that may influence the distribution of these pathogens is breed, as $B$. indicus cattle, because of tick resistance, are less likely to be infected by ticks. Also, management of the herds, with excessive use of acaricides and rotational grazing appears to be related to outbreaks of babesiosis and anaplasmosis, especially in dairy cattle (GUGLIELMONE, 1995; RIKHOTSO et al., 2005; D’ ANDREA et al., 2006).

Other relevant hemoparasitic disease is tripanosomosis by Trypanosoma vivax. In South America, this hemoprotozoan is transmitted by hematophagous diptera, mainly tabanids (GARDINER, 1989; OTTE; ABUABARA, 1991; JONES; DÁVILA, 2001). In the Brazilian territory, T. vivax was first described in the State of Pará infecting water buffalo (Bubalis bubalis) (SHAW; LAINSON, 1972). Only 24 years latter, $T$. vivax was reported in other parts of the country, in the Pantanal of Mato Grosso (SILVA et al., 1996) and one year later in the Pantanal of Mato Grosso do Sul (PAIVA et al., 2000). More recently, T. vivax was described in the semi-arid of the State of Paraíba (BATISTA et al., 2007). In Brazil, this hemoprotozoan was described causing fever, lethargy, weakness, anemia, diarrhea, abortion and even death of infected animals (SILVA et al., 1996; BATISTA et al., 2007).

Borrelia theileri is a worldwide tickborne spirochete that infects cattle and other mammals. In cattle, the infection can be characterized by fever, lethargy and anemy. This agent is specially important because $B$. theileri infection induces crossreacting antibodies that could interfere with interpretation of seroepidemiologic studies of other bovine borreliae (ROGERS et al., 1999).

This study shows a serologic survey for antibodies to Babesia bigemina, B. bovis, Anaplasma marginale, Trypanosoma vivax and homologous to Borrelia burgdorferi in cattle from the Northeastern region of the State of Pará and the discussion of epidemiological data, such as the endemicity status of the infectious agents.

\section{MATERIAL AND METHODS}

Serum samples were obtained from 246 adult female cattle, selected by convenience, from the municipalities of Castanhal ( 65 beef cattle, Nelore breed) and São Miguel do Guamá (181 dairy cattle, crossbred), Northeastern region of State of Pará. These municipalities have 82,693 cattle, corresponding to $0.47 \%$ of the cattle population from the State of Pará (IBGE, 2006).

Serum samples were analyzed by indirect enzyme-linked immunosorbent assays (ELISAs) with crude antigens of $B$. bigemina, B. bovis, T. vivax (MADRUGA et al. 2000, 2001, 2006) and B. burgdorferi according to Ishikawa et al. (1997). Anaplasma marginale antibodies were detected by indirect ELISA, using recombinant MSP1a as antigen (ARAÚJO et al., 2005). Cutoffs were calculated for each ELISA plate, according to Frey et al. (1998), with 12 negative sera for each organism.

Statistical analyses were done by Qui-square or Fischer's exact tests, with a confidence level of 95\%. 
Table 1. Frequencies of seropositive cattle to Babesia bigemina, B. bovis, Anaplasma marginale, Trypanosoma vivax and Borrelia burgdorferi in cattle from the municipalities of Castanhal and São Miguel do Guamá, Northeastern region of Pará State, Brazil.

\begin{tabular}{|c|c|c|c|c|c|c|}
\hline \multirow[t]{2}{*}{ Organism } & \multicolumn{2}{|c|}{ Castanhal $(n=65)$} & \multicolumn{2}{|c|}{ São Miguel Guamá $(n=181)$} & \multicolumn{2}{|c|}{ Total $(n=246)$} \\
\hline & Positive & $(\%)$ & Positive & $(\%)$ & Positive & $(\%)$ \\
\hline Babesia bigemina & 64 & (98.5) & 180 & (99.4) & 244 & $(99.2)$ \\
\hline B. bovis & 62 & (95.4) & 181 & (100) & 243 & (98.8) \\
\hline Anaplasma marginale & 43 & (66.2) & 125 & (69.1) & 168 & (68.3) \\
\hline Trypanosoma vivax & 54 & (83.0) & 175 & (96.7) & 229 & (93.1) \\
\hline Borrelia burgdorferi & 24 & (36.9) & 111 & (61.3) & 135 & (54.9) \\
\hline
\end{tabular}

$\mathrm{n}=$ Number of samples.

\section{RESULTS AND DISCUSSION}

From the 246 serum samples analyzed, 244 (99.2\%), 243 (98.8\%), 168 (68.3\%), and 229 (93.1\%) were positive for antibodies to B. bigemina, B. bovis, A. marginale, and T. vivax, respectively (Table 1$)$ and, 135 (54.9\%) were positive for homologues antibodies to B. Burgdorferi.

Frequencies of seropositive animals to $B$. bovis and $B$. bigemina were significantly higher $(\mathrm{P}<0.001)$ than those to $A$. marginale or T. vivax. Also, frequencies of seropositive cattle to $T$. vivax were significantly higher than that to $A$. marginale $(\mathrm{P}<0.001)$.

Differences in the frequencies of antibodies between Castanhal and São Miguel do Guamá were significant only for antibodies to B. bovis $(\mathrm{P}=0.018)$ and T. vivax $(\mathrm{P}<0.001)$, whose frequencies were higher in São Miguel do Guamá, were cross-bred dairy cattle were sampled. The effect of climatic conditions possibly is not related to these differences, as both municipalities are contiguous, and share the same meteorological conditions.

Frequencies of seropositive cattle to $B$. bovis and $B$. bigemina suggest a high rate of transmission of these organisms by tick in the studied region, which can be classified as enzootically stable to these hemoprotozoans (MAHONEY; ROSS 1972). This is suggestive that the risk of outbreaks of babesiosis is low and vaccination of native herds is not necessary.

The significantly lower frequency of antibodies to $A$. marginale may be attributed to a low rate of transmission by ticks or diptera, but this is hard to explain, in face of the high frequencies of antibodies to Babesia sp. Another possibility is a lower sensitivity of the recombinant MSP1a ELISA. If so, this is not in agreement with Araújo et al. (2005), who found a sensitivity of $99 \%$ for this test, with sera from naturally-infected cattle, positive for antibodies to A. marginale by IFAT. Silva et al. (2006) did not find differences in the performances of ELISAs with crude antigen and with MSP5 as antigens to detect antibodies to $A$. marginale.

The high frequency of antibodies to T. vivax is suggestive of an efficient mechanical transmission of this hemoprotozoan by hematophagous diptera (mainly tabanids), as biological vectors are not found in South America (GARDINER et al., 1989; OTTE; ABUABARA, 1991; JONES; DÁVILA, 2001). In Brazil, the first record of T. vivax was done in the State of
Pará, in water buffalo (SHAW; LAINSON, 1972). A recent epidemiological survey showed the presence of specific antibodies to this hemoprotozoan in different regions of the State of Pará (MADRUGA et al., 2006). These data and those found in this study indicate that T. vivax is possibly widespread in the State of Pará.

In Brazil, T. vivax has been involved with chronic and asymptomatic infection (VENTURA et al., 2001; DÁVILA et al., 2003), but clinical cases have been recorded, with cattle showing anemia, weight loss, hypoglycemia, and nervous signs (BATISTA et al., 2007). In this context, studies to evaluate the economic impact of this hemoprotozoan in the State of Pará are necessary.

The subclinical aspects of $B$. theileri infection described by Rogers et al. (1999) were observed in this study. The occurrence of the Lyme disease like syndrome referred by Mantovani et al. (2007) in Brazil, justify the seroepidemiological study in cattle, because of the crossreacting antibodies between Borrelia theileri and other species of Borrelia genus (ROGERS et al., 1999). The rate of cattle that showed homologues antibodies to $B$. burgdorferi indicates the presence of the tickborne spirochaetal agent in the herds evaluated. More studies should be done to evaluate the risk to human of this Borrelia species present in cattle.

\section{REFERENCES}

ARAÚJO, F. R.; MADRUGA, C. R.; LEAL, C. R.; SCHENK, M. A.; KESSLER, R. H.; MARQUES, A. P.; LEMAIRE, D. C. Comparison between enzyme-linked immunosorbent assay, indirect fluorescent antibody and rapid conglutination tests in detecting antibodies against Babesia bovis. Veterinary Parasitology, v. 74, n. 2-4, p. 101-108, 1998.

ARAÚJO, F. R.; MELO, V. S. P.; RAMOS, C. A. N.; MADRUGA, C. R.; SOARES, C. O.; KESSLER, R. H.; ALMEIDA, N. F.; ARAÚJO, G. S.; TORRES, R. A. A. JR.; FRAGOSO, S. P.; ARAUCO, P. R. C.; BACANELLI, G.; OLIVEIRA, M. B; SANTOS, L. R. Development of enzyme-linked immunoadsorbent assays based on recombinant MSP1a and MSP2 of Anaplasma marginale. Memórias do Instituto Oswaldo Cruz, v. 100, n. 7, p. 765769, 2005.

BARROS, S. L.; MADRUGA, C. R.; ARAÚJO, F. R.; MENK, C. F.; ALMEIDA, M. A. O.; MELO, E. P. S.; KESSLER, 
R. H. Serological survey of Babesia bovis, Babesia bigemina, and Anaplasma marginale antibodies in cattle from the semi-arid region of the state of Bahia, Brazil, by enzyme-linked immunosorbent assays. Memórias do Instituto Oswaldo Cruz, v. 100, n. 6, p. 613-617, 2005.

BATISTA, J. S.; RIET-CORREA, F.; TEIXEIRA, M. M.; MADRUGA, C. R.; SIMOES, S. D.; MAIA, T. F. Trypanosomiasis by Trypanosoma vivax in cattle in the Brazilian semiarid: Description of an outbreak and lesions in the nervous system. Veterinary Parasitology, v. 143, n. 2, p. 174-181, 2007.

BOCK, R.; JACKSON, L.; VOS, A. de, JORGENSEN, W. Babesiosis of cattle. Parasitology, v. 129, Supl. 51, S247S269, 2004.

D’ANDREA, L. A. Z.; SARTOR, I. F.; MADRUGA, C. R.; FREITAS, S. B. Z.; KROLL, L. B.; KRONKA, S. N. Immunological condition of cattle in Holstein and Nelore breed in regard to Babesia bovis and B. bigemina in two regions of the State of São Paulo. Pesquisa Veterinária Brasileira, v. 26, n. 2, p. 74-78, 2006.

DÁVILA, A. M.; HERRERA, H. M.; SCHLEBINGER, T.; SOUZA, S. S.; TRAUB-CSEKO, Y. M. Using PCR for unraveling the cryptic epizootiology of livestock trypanosomosis in the Pantanal, Brazil. Veterinary Parasitology, v. 117, n. 1-2, p. 1-13, 2003.

FREY, A.; DI CANZI, J.; ZURAKOWSKI, D. A statistically defined endpoint titer determination method for immunoassays. Journal of Immunological Methods, v. 221, n. 1-2, p. 35-41, 1998.

GARDINER, P. R. Recent studies of the biology of Trypanosoma vivax. Advances in Parasitology, v. 28, p. 229-317, 1989.

GUGLIELMONE, A. A. Epidemiology of babesiosis and anaplasmosis in South and Central America. Veterinary Parasitology, v. 57, n. 1-3, p. 109-119, 1995.

IBGE. Efetivos dos rebanhos de grande porte em 31.12, segundo as Unidades da Federação, Mesorregiões, Microrregiões e Municípios produtores, 2006. Disponível em: <ftp://ftp.ibge.gov.br/Producao_Pecuaria/Producao_da_Pecuaria_Municipal_\%5Banual\%5D/2006/ UFs_e_Grandes_Regioes.zip.>. Acesso em: 08 abr. 2008.

ISHIKAWA M. M.; FONSECA A. H.; SOARES C. O.; MASSARD C. L.; YOSHINARI, N. H. Padronização de ensaio imunoenzimático ELISA indireto para pesquisa de anticorpos IgG contra Borrelia burgdorferi em bovinos. Revista Brasileira de Medicina Veterinária, v. 19, n. 4, p.166-168, 1997.

JONES, T. W.; DÁVILA, A. M. Trypanosoma vivax-out of Africa. Trends in Parasitology, v. 17, n. 2, p. 99-101, 2001

KOCAN, K. M.; FUENTE, J.; GUGLIELMONE, A. A.; MELENDEZ, R. D. Antigens and alternatives for control of Anaplasma marginale infection in cattle. Clinical Microbiology Reviews, v. 16, n. 4; p. 698-712, 2003.

MADRUGA, C. R.; ARAUJO, F. R.; CAVALCANTE-GOES, G.; MARTINS, C., PFEIFER, I. B.; RIBEIRO, L. R.;
KESSLER, R. H.; SOARES, C. O.; MIGUITA, M., MELO, E. P., ALMEIDA, R. F.; LIMA, M. M. JR. The development of an enzyme-linked immunosorbent assay for Trypanosoma vivax antibodies and its use in epidemiological surveys. Memórias do Instituto Oswaldo Cruz, v. 101, n. 7, p. 801-807, 2006.

MADRUGA, C. R.; MARQUES, A. P. C.; ARAÚJO, F. R.; MIGUITA, M.; CARVALHO, C. M. E.; ARAÚJO, F. S.; UMAKI, A. C. S.; CROCCI, A. J.; QUEIRÓZ, R. A. Evaluation of an ELISA for detection of antibodies to Babesia bigemina in cattle and it's application in an epidemiological survey in Brazil. Pesquisa Veterinária Brasileira, v. 21, n. 2, p. 72-76, 2001.

MADRUGA, C. R.; MARQUES, A. P. C.; LEAL, C. R. B.; CARVALHO, C. M. E.; ARAÚJO, F. R.; KESSLER, R. H. Evaluation of an enzyme-linked immunosorbent assay to detect antibodies against Anaplasma marginale. Pesquisa Veterinária Brasileira, v. 20, n. 3, p. 109-112, 2000.

MAHONEY, D. F.; ROSS, D. R. Epizootiological factors in the control of bovine babesiosis. Australian Veterinary Journal, v. 48, n. 5; p. 292-298, 1972.

MANTOVANI, E.; COSTA, I. P.; GAUDITANO, G.; BONOLDI, V. L. N.; HIGUCHI, M. L.; YOSHINARI, N $\mathrm{H}$. Description of Lyme disease-like syndrome in Brazil. Is it a new tick borne disease or Lyme disease variation? Brazilian Journal of Medical and Biological Research, v. 40, n. 4; p. 443-456, 2007.

MELENDEZ, R. D. Future perspectives on veterinary hemoparasite research in the tropics at the start of this century. Annals of the New York Academy of Sciences, v. 916, p.253-258, 2000.

MELO, V. S. P.; PASSOS, L. M. F.; FACURY-FILHO, E. J.; SATURNINO, H. M.; RIBEIRO, M. F. B. Natural infection of calves by in dairy herds of the Metalúrgica Region, Minas Gerais. Pesquisa Veterinária Brasileira, v. 21, n. 4, p.146-150, 2001.

OTTE, M. J.; ABUABARA, J. Y. Transmission of South American Trypanosoma vivax by the neotropical horsefly Tabanus nebulosus. Acta Tropica, v. 49, n. 1, p. 73-76, 1991.

PAIVA, F.; LEMOS, R. A. A. de; NAKAZATO, L.; MORI, A. E.; BRUM, K. B.; BERNARDO, K. C. B. Trypanosoma vivax em bovinos no Pantanal do Estado do Mato Grosso do Sul, Brasil: I. - Acompanhamento clínico, laboratorial e anatomopatológico de rebanhos infectados. Revista Brasileira de Parasitologia Veterinária, v. 9, n. 2, p. 135-141, 2000.

RIKHOTSO, B. O. ; STOLTSZ, W. H.; BRYSON, N. R.; SOMMERVILLE, J. E. The impact of 2 dipping systems on endemic stability to bovine babesiosis and anaplasmosis in cattle in 4 communally grazed areas in Limpopo Province, South Africa. Journal of the South African Veterinary Association, v. 76, n. 4, p. 217-223, 2005.

ROGERS, A. B.; SMITH, R. D.; KAKOMA, I. Serologic cross-reactivity of antibodies against Borrelia theileri, Borrelia burgdorferi and Borrelia coriaceae in cattle. 
American Journal of Veterinary Research, v. 60, n. 6, p. 694-697, 1999.

SHAW, J. J.; LAINSON, R. Trypanosoma vivax in Brazil. Annals of Tropical Medicine and Parasitology, v. 66, n. 1, p. 25-32, 1972.

SILVA, R. A.; DA SILVA, J. A.; SCHNEIDER, R. C.; DE FREITAS, J.; MESQUITA, D.; MESQUITA, T.; RAMIREZ, L.; RIVERA DÁVILA, A. M.; PEREIRA, M. E. Outbreak of trypanosomiasis due to Trypanosoma vivax (Ziemann, 1905) in bovines of the Pantanal, Brazil. Memórias do Instituto Oswaldo Cruz, v. 91, n. 5, p.561-562, 1996.

SILVA, V. M.; ARAUJO, F. R.; MADRUGA, C. R.; SOARES, C. O.; KESSLER, R. H.; ALMEIDA, M. A.; FRAGOSO, S. P.; SANTOS, L. R.; RAMOS, C. A.; BACANELLI, G.; TORRES, R. A. Comparison between indirect enzyme-linked immunosorbent assays for Anaplasma marginale antibodies with recombinant major surface protein 5 and initial body antigens. Memórias do Instituto Oswaldo Cruz, v. 101, n. 5, p. 511-516, 2006.

SMITH, R. D.; EVANS, D. E.; MARTINS, J. R.; CERESÉR,
V. H.; CORREA, B. L.; PETRACCIA, C.; CARDOZO, H.; SOLARI, M. A.; NARI, A. Babesiosis (Babesia bovis) stability in unstable environments. Annals of the New York Academy of Sciences, v. 916, p. 510-520, 2000.

SOARES, C. O.; SOUZA, SOUZA, J. C. P.; MADRUGA, C. R.; MADUREIRA, R. C. ; MASSARD, C. L., FONSECA, A. H. Seroprevalence of Babesia bovis in cattle in the “Norte Fluminense” mesoregion. Pesquisa Veterinária Brasileira, v. 20, n. 2, p. 75-79, 2000.

SOUZA, J. C. P.; SOARES, C. O.; MASSARD, C. L.; SCOFIELD, A. ; FONSECA, A. H. Seroprevalence of Anaplasma marginale in cattle in the "Norte Fluminense" mesoregion. Pesquisa Veterinária Brasileira, v. 20, n. 3, p. 97-101, 2000 .

VENTURA, R. M.; PAIVA, F., SILVA, R. A.; TAKEDA, G. F.; BUCK, G. A.; TEIXEIRA, M. M. Trypanosoma vivax: characterization of the spliced-leader gene of a Brazilian stock and species-specific detection by PCR amplification of an intergenic spacer sequence. Experimental Parasitology, v. 99, n. 1, p. 37-48, 2001.

Received on October 30, 2007.

Accepted for publication on June 24, 2008. 